\title{
The effect of dietary protein on breast meat yield of broilers reared on different daylengths
}

\author{
P.P. Mlaba, M. Ciacciariello \& R.M. Gous ${ }^{\#}$ \\ Animal and Poultry Science, University of KwaZulu-Natal, Pietermaritzburg, South Africa
}

(Received 21 February 2014; Accepted 23 February 2015; First published online 2 March 2015)

\begin{abstract}
Copyright resides with the authors in terms of the Creative Commons Attribution 2.5 South African Licence.
See: http://creativecommons.org/licenses/by/2.5/za

Condition of use: The user may copy, distribute, transmit and adapt the work, but must recognise the authors and the South African Journal of Animal Science.
\end{abstract}

\begin{abstract}
The objective of the trial reported here was to determine whether breast meat yield would improve in broilers reared on short daylengths if higher levels of dietary protein were fed. To that end, 3200 Ross 308 International broilers were reared to $35 \mathrm{~d}$ in eight light-tight rooms, each room being divided into four pens which were populated with 100 feather-sexed male or female chicks. The lighting treatments used were 12 ,

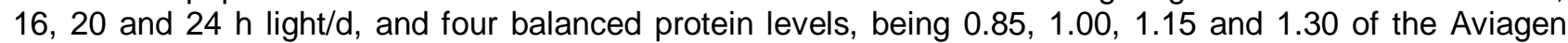
amino acid recommendations, were fed. At $35 \mathrm{~d}$, three birds from each pen were sacrificed for measurement, individually, of physical and chemical characteristics. Body weight gain to $35 \mathrm{~d}$ was unaffected by both dietary protein content and light. FCE increased with dietary protein content to day 21 . Feed intake to day 35 was not influenced by light or by dietary protein content. Birds on $24 \mathrm{~h}$ had a higher mortality compared with those on the three other lighting programmes, which did not differ from one another. Body protein content increased with both daylength and dietary protein content whereas body lipid content was influenced (decreased) only by dietary protein. Breast meat yield from birds reared on $12 \mathrm{~h}$ was not improved when these birds were fed high protein feeds whereas yields were increased in birds on the three longer daylengths used when feed protein was increased. The decreased breast meat yield in broilers given short daylengths is therefore not the consequence of a shortage of dietary protein.
\end{abstract}

Keywords: Thigh, drum, wing, carcass yield

\# Corresponding author: gous@ukzn.ac.za

\section{Introduction}

Breast meat yield has been shown to be reduced when birds are exposed to daylengths shorter than $20 \mathrm{~h}$ whereas most other important biological parameters showed improved performance. Unpublished data from studies commissioned by Aviagen showed that breast yields at 31, 38 and $49 \mathrm{~d}$ progressively increased as photoperiod was lengthened from 14 to $23 \mathrm{~h}$ light, and Schwean-Lardner et al. (2006) noted that, at $38 \mathrm{~d}$ of age, birds given 23-h photoperiods had larger breasts than those on $14 \mathrm{~h}$. Brickett et al. (2007) reported lower breast yield for 35-d Ross 308 birds given 12-h photoperiods than those given $20 \mathrm{~h}$. The superior breast yields at $54 \mathrm{~d}$ in both Ross and Cobb genotypes given $>21 \mathrm{~h}$ photoperiods (Lewis et al., 2009) are in agreement with the findings of Renden et al. (1992; 1993; 1996) and Lien et al. (2007) for 49-d birds, and with Downs et al. (2006) for 56-d birds. Whilst continuous lighting increases breast meat yield it also increases physiological stress levels and mortality (Lewis et al., 2008). As yet, no explanation has been given for the lower breast meat yield of broilers reared on shorter daylengths, but because of the welfare benefits of such a management procedure, it is worth finding a way of overcoming this hurdle. The new welfare regulations in the European Union stipulate that birds should be exposed daily to a minimum of $8 \mathrm{~h}$ of darkness, six of which must be un-interrupted within a 24-hour cycle (European Union, 2007). Therefore, a maximum of only $16 \mathrm{~h}$ of light will be permissible in the future.

Studies by Danisman \& Gous $(2011 ; 2013)$ have shown that body protein content is positively associated with breast meat yield and that this relationship is constant across genotypes and sexes. It is only when low protein feeds are offered to broilers that the relationship between body protein and breast meat yield changes (Danisman \& Gous, 2011; 2013). Under these circumstances, excess energy is consumed by birds in their attempt to consume sufficient protein which results in an increase in lipid deposition in the various parts of the body (Gous et al., 1990; Smith \& Pesti, 1998) causing the allometric 
relationship between breast meat yield and body protein to differ from that where high protein feeds are offered (Danisman \& Gous, 2011; 2013). It is possible that the reduced feed intake of broilers reared on short daylengths (Ingram et al., 2000, Lewis et al., 2009) may result in less dietary protein being consumed than is necessary to meet the potential body protein growth of broilers, and this could be the cause of the lower breast meat yield in birds reared on short daylengths. Alternatively, the lower energy usage by birds on short daylengths would result in a surplus which would be deposited as body lipid (Lewis \& Gous, 2007). Therefore, at the same body weight as broilers on long daylengths, broilers on short daylengths would have more body lipid and hence less body protein, and as a result, less breast meat.

The hypothesis tested in this trial was that breast meat yield would improve in broilers reared on short daylengths if higher levels of dietary protein were fed. In order to test this hypothesis, feeds ranging in dietary protein content were fed to broilers reared under a range of daylengths, with growth rate, feed intake, breast meat yield and body protein and lipid content being measured.

\section{Materials and Methods}

A total of 3200 day-old Ross 308 International broiler chicks was reared in eight light-tight rooms. Each room was divided into four pens using a mesh fence as a barrier. Each pen was populated with 100 feather-sexed male or female chicks. On the first day all chicks received continuous lighting, with the lighting treatments being implemented from the second day of age. Illumination was provided by 11W warm-white compact fluorescent lamps. Heating was provided initially using gas spot-brooders which were placed over two pens on either side of each room. The room temperature was set initially at $32^{\circ} \mathrm{C}$ and was decreased by $3^{\circ} \mathrm{C}$ at seven $\mathrm{d}$ and then linearly to reach $20^{\circ} \mathrm{C}$ by $21 \mathrm{~d}$ of age. The Animal Ethics Committee approved, in 2010, the use of broiler chickens for this study (reference number: 086/10/Animal).

The four experimental diets used, were formulated to contain $0.85,1.00,1.15$ and 1.30 of the Aviagen amino acid recommendations (Aviagen, 2009) in the starter and grower periods. Two basal feeds (lowest and highest balanced protein levels) (Table 1) were mixed at a commercial mill, and the chemical composition for these feeds is given in Table 2. The two intermediate levels of balanced protein were produced by blending the high and low protein basal feeds in the ratios $0.67: 0.33$ and $0.33: 0.67$, respectively. The basal feeds were sampled after mixing for the analysis of apparent metabolisable energy (AME) and digestible amino acid content, using the method of Fisher \& McNab (1987) and a Waters amino acid analyser (AOAC, 2003). The experimental diets were provided in a crumbled form for the first two weeks and in a pelleted form thereafter. Feed and water were supplied ad libitum for the entire trial, and drinkers were cleaned daily.

On arrival, all chicks were weighed per box to obtain their mean initial body weight. Thereafter a random sample of the birds in each pen was weighed at seven-day intervals and these values were used to calculate BWG. On the same day, feed remaining in the troughs was measured from which feed consumption was calculated. Mortality was recorded daily and feed intake was corrected for mortality. Feed conversion efficiency (FCE) was calculated as $\mathrm{g}$ gain $/ \mathrm{kg}$ feed consumed.

At $35 \mathrm{~d}$, three birds from each pen were sacrificed for measurement of physical and chemical characteristics. Body weight of each bird was recorded three times, once before being electrically stunned and exsanguinated, the second after bleeding had ceased, and finally after the feathers had been removed using a rotatory drum plucker. Breast meat (without bone or skin), thigh, drum and wing (with skin and bone) were dissected and weighed and then all parts of each bird, other than feathers, were sealed in a plastic bag, marked and stored in a freezer until mincing took place. Each bird was minced twice using a medium sized mincing machine after which a sample of approximately $500 \mathrm{~g}$ was taken from each carcass for subsequent chemical analysis. Each carcass sample was freeze-dried and then milled using a Retsch ultracentrifugal mill. The crude protein content $(\mathrm{N} \times 6.25)$ of each milled sample was analysed with a LECO FP2000 Nitrogen analyser using the Dumas combustion method (AOAC, 2003). Gross energy (GE) content was determined using a DDS isothermal CP 500 bomb calorimeter. Lipid (L) content was calculated from GE using the equation $L=-0.8754+0.04754^{*} G E$ (University of KwaZulu-Natal, unpublished). To determine the ash content, samples were placed in a furnace for four hours at $550^{\circ} \mathrm{C}$ (AOAC, 2003).

Four lighting treatments, namely $12 \mathrm{~L}: 12 \mathrm{D}, 16 \mathrm{~L}: 8 \mathrm{D}, 20 \mathrm{~L}: 4 \mathrm{D}$ and $24 \mathrm{~L}: 0 \mathrm{D}$ were applied from day old for the duration of the trial, these being randomised between rooms, with each lighting treatment being replicated twice, resulting in a factorial design with two sexes, four dietary protein levels and four lighting treatments. Data were analysed using analysis of variance to determine treatment means. Simple linear regression with groups was used to evaluate the response to dietary protein content and daylength, using Genstat (2011). Birds were sexed at the hatchery and reared separately, but to allow for the maximum number of replications of the main effects (light and dietary protein), sex was not included in the statistical analysis and birds were treated as 'as-hatched'. The Chi-square test was used to determine the effects of photoperiod and dietary protein content on mortality (Morris, 1999). 
Table 1 Ingredient and nutrient composition $(\mathrm{g} / \mathrm{kg})$ of low and high protein basal feeds used in the starter and finisher periods of the trial

\begin{tabular}{|c|c|c|c|c|}
\hline \multirow{2}{*}{ Feed ingredients } & \multicolumn{2}{|c|}{ Starter } & \multicolumn{2}{|c|}{ Finisher } \\
\hline & LP & HP & LP & HP \\
\hline Maize & 591 & 320 & 730 & 553 \\
\hline Wheat middlings & & & 23.2 & \\
\hline Soybean full fat & 300 & 300 & 202 & 300 \\
\hline Soybean oilcake & 60.8 & 255 & & 92.3 \\
\hline Fish meal & & 45.0 & & \\
\hline L-lysine $\mathrm{HCl}$ & 3.00 & 2.40 & 2.00 & 1.80 \\
\hline DL methionine & 1.60 & 2.3 & 0.50 & 1.90 \\
\hline L-threonine & 0.80 & 1.00 & 0.40 & 0.70 \\
\hline Choline chloride $60 \%$ & 0.80 & & 1.40 & 0.70 \\
\hline Vit+min premix & 1.50 & 1.50 & 1.50 & 1.50 \\
\hline Limestone & 17.1 & 12.8 & 18.1 & 17.0 \\
\hline Salt & 2.00 & 1.20 & 2.00 & 2.20 \\
\hline Monocalcium phosphate & 16.5 & 12.6 & 16.5 & 16.5 \\
\hline Sodium bicarbonate & 2.40 & 1.80 & 2.50 & 2.00 \\
\hline Oil - sunflower & 2.10 & 44.4 & & 10.9 \\
\hline \multicolumn{5}{|l|}{ Composition (calculated) } \\
\hline AMEn adult $(\mathrm{MJ} / \mathrm{kg})$ & 12.6 & 12.6 & 13.0 & 13.0 \\
\hline Crude protein (g/kg) & 194 & 290 & 143 & 204 \\
\hline Lysine $^{1}$ & 11.6 & 17.4 & 7.60 & 11.4 \\
\hline Methionine & 4.20 & 6.20 & 2.70 & 4.60 \\
\hline Methionine+cystine & 6.90 & 9.70 & 5.00 & 7.40 \\
\hline Threonine & 7.10 & 10.7 & 5.00 & 7.40 \\
\hline Tryptophan & 1.80 & 2.90 & 1.20 & 2.00 \\
\hline Arginine & 11.7 & 18.5 & 8.00 & 12.6 \\
\hline Isoleucine & 7.50 & 11.9 & 5.20 & 8.00 \\
\hline Valine & 8.40 & 12.6 & 6.10 & 8.90 \\
\hline Calcium & 10.0 & 10.0 & 10.0 & 10.0 \\
\hline Avail. Phosphorous & 5.00 & 5.00 & 5.00 & 5.00 \\
\hline
\end{tabular}

${ }^{1}$ The amino acid composition is measured on a digestible basis.

\section{Results}

Protein contents of the four starter feeds were measured to be 194, 226, 258 and $290 \mathrm{~g} / \mathrm{kg}$, and in the finisher feeds, 143, 164, 184 and $204 \mathrm{~g} / \mathrm{kg}$, respectively, confirming that the blending of the intermediate feeds had taken place accurately. Mean body weight gain (BWG), feed intake and FCE of birds on the four dietary protein levels and subjected to four lighting treatments to $35 \mathrm{~d}$ of age is given in Table 2. There were no significant interactions between lighting programme and dietary protein content for any of the measured variables $(P>0.05)$. BWG to $35 \mathrm{~d}$ was unaffected by both dietary protein content ( $b=0.84 \pm 1.12 \mathrm{~g} / \mathrm{g}$ protein) and light $(b=5.78 \pm 5.46 \mathrm{~g} / \mathrm{h}$ light). FCE increased with dietary protein content to day 21 only ( $b=0.626 \pm$ $0.266 \mathrm{~g}$ gain $/ \mathrm{kg}$ feed intake/g protein). Feed intake to day 35 was not influenced by light ( $b=7.61 \pm 7.18 \mathrm{~g} / \mathrm{h}$ light) or by dietary protein content $(b=-0.41 \pm 1.4 \mathrm{~g} / \mathrm{g}$ protein).

Birds on $24 \mathrm{~h}$ had a higher $(P<0.05)$ mortality $(5.58 \%)$ compared with those on the three other lighting programmes, which did not differ from one another. Dietary protein content did not affect mortality $(P>0.05)$. 
Mean breast weights of the broilers sampled at $35 \mathrm{~d}$ are given in Table 3 . There was no change in breast weight with dietary protein content $(-0.338 \pm 0.518 \mathrm{~g} / \mathrm{g})$ except when birds were subjected to $20 \mathrm{~h}$ light, when breast meat increased by $2.541 \pm 0.733 \mathrm{~g} / \mathrm{g}$ dietary protein (Figure 1$)$. However, the slope of the response to increasing daylengths differed depending on the dietary protein offered: for the lowest protein content $(143 \mathrm{~g} / \mathrm{kg})$ this decreased linearly by $(-) 2.12 \pm 1.09 \mathrm{~g} / \mathrm{h}$ light. On the next two highest protein levels $(164$ and $184 \mathrm{~g} / \mathrm{kg}$ ) the increasing linear response was the same $(5.35 \pm 2.72 \mathrm{~g} / \mathrm{h})$; and at the highest dietary protein content the response was curvilinear, increasing to the highest weight on $20 \mathrm{~h}$ light and then decreasing, the coefficients being $99.6 \pm 27.9$ for the linear term, and $-2.63 \pm 0.77$ for the quadratic term. These responses are illustrated in Figure 2 . Birds on $20 \mathrm{~h}$ of light and fed the highest protein content had the heaviest breast weights.

Table 2 Mean body weight gain ( $\mathrm{g}$ ), feed intake ( $\mathrm{g}$ ) and feed conversion efficiency ( $\mathrm{g}$ gain/ $\mathrm{kg}$ feed consumed) at 21 and $35 \mathrm{~d}$, of birds fed four levels of dietary protein under four lighting treatments

\begin{tabular}{|c|c|c|c|c|c|c|c|c|c|c|}
\hline \multirow[b]{2}{*}{ Light (h) } & \multicolumn{10}{|c|}{ Dietary protein content (g/kg feed) } \\
\hline & 194 & 226 & 258 & 290 & Mean & 143 & 164 & 184 & 204 & Mean \\
\hline & \multicolumn{10}{|c|}{ Body weight gain } \\
\hline & \multicolumn{5}{|c|}{$0-21 d$} & \multicolumn{5}{|c|}{$22-35 d$} \\
\hline 12 & 941 & 866 & 845 & 942 & 899 & 1363 & 1363 & 1389 & 1450 & 1391 \\
\hline 16 & 866 & 857 & 866 & 911 & 875 & 1311 & 1402 & 1405 & 1425 & 1386 \\
\hline 20 & 889 & 883 & 914 & 935 & 905 & 1359 & 1397 & 1465 & 1579 & 1450 \\
\hline 24 & 913 & 947 & 952 & 953 & 941 & 1440 & 1461 & 1406 & 1481 & 1447 \\
\hline Mean & 902 & 888 & 894 & 935 & & 1368 & 1406 & 1416 & 1484 & \\
\hline \multirow[t]{3}{*}{ RMS } & \multicolumn{5}{|c|}{2534} & \multicolumn{5}{|c|}{29879} \\
\hline & \multicolumn{10}{|c|}{ Feed intake } \\
\hline & \multicolumn{5}{|c|}{$0-21 d$} & \multicolumn{5}{|c|}{$22-35 d$} \\
\hline 12 & 1200 & 1107 & 1006 & 1147 & 1115 & 2488 & 2363 & 2244 & 2492 & 1685 \\
\hline 16 & 1129 & 1088 & 1057 & 1071 & 1086 & 2409 & 2401 & 2424 & 2357 & 1669 \\
\hline 20 & 1159 & 1163 & 1117 & 1139 & 1144 & 2418 & 2467 & 2463 & 2490 & 1729 \\
\hline 24 & 1190 & 1118 & 1131 & 1139 & 1145 & 2531 & 2503 & 2423 & 2453 & 1737 \\
\hline Mean & 1169 & 1119 & 1078 & 1124 & & 2462 & 2434 & 2389 & 2448 & \\
\hline \multirow[t]{3}{*}{ RMS } & \multicolumn{5}{|c|}{4664} & \multicolumn{5}{|c|}{54780} \\
\hline & \multicolumn{10}{|c|}{ Feed conversion efficiency } \\
\hline & \multicolumn{5}{|c|}{$0-21 d$} & \multicolumn{5}{|c|}{$21-35 d$} \\
\hline 12 & 750 & 746 & 799 & 788 & 770 & 548 & 576 & 619 & 583 & 582 \\
\hline 16 & 730 & 749 & 780 & 811 & 768 & 544 & 584 & 579 & 604 & 578 \\
\hline 20 & 731 & 725 & 781 & 783 & 755 & 562 & 565 & 593 & 633 & 588 \\
\hline 24 & 732 & 809 & 805 & 799 & 786 & 569 & 583 & 579 & 601 & 583 \\
\hline Mean & 736 & 757 & 791 & 795 & & 556 & 577 & 592 & 605 & \\
\hline RMS & \multicolumn{5}{|c|}{580} & \multicolumn{5}{|c|}{643} \\
\hline
\end{tabular}

RMS: Residual mean square; $\mathrm{n}=32$.

When breast weight was expressed as a proportion of body weight (BRW/BW) both feed protein content and daylength influenced this ratio $(P>0.05)$ although there was no significant interaction between the two factors (Table 4). When breast weight was expressed as a proportion of body protein weight (BRW/BPW), the only observed difference was between lighting treatments (Table 4). These differences were reduced even further when the allometric relationship between breast meat and body protein weight was analysed: The slope of the regression was the same for all treatments $(0.988 \pm 0.444)$ but the constant term differed for those birds fed $204 \mathrm{~g}$ protein $/ \mathrm{kg}$, being $1.447 \pm 0.115$ for birds on $12 \mathrm{~h}$ light and $1.701 \pm$ 0.139 for birds on $20 \mathrm{~h}$ light. For all other combinations of light and feed protein the constant term was 1.562 \pm 0.435 . 
Mean thigh weights (average weight per bird) for broilers at $35 \mathrm{~d}$ are shown in Table 3 . Males had higher mean weights than females ( $136 \mathrm{vs} .114 \mathrm{~g}, P<0.001)$. There was no effect of dietary protein content ( $b=0.123 \pm 0.087 \mathrm{~g} / \mathrm{g}$ protein) or light $(b=-0.065 \pm 0.440 \mathrm{~g} / \mathrm{h}$ light) on thigh weight, but an interaction between these factors resulted in thigh weights increasing, in birds fed dietary protein levels of 164, 184 and $204 \mathrm{~g} / \mathrm{kg}$, as daylength was increased, but with birds on the lowest protein (143 g protein/ $\mathrm{kg}$ feed) showing reduced thigh weights $(P<0.05)$. The allometric relationship (constant term and regression coefficient) between $(I n)$ mean thigh weight and $(I n)$ body protein weight was the same over all dietary protein and lighting treatments, being represented by the equation $0.034 \pm 0.418+0.8336 \pm 0.0729 \mathrm{~g} / \mathrm{g}$.

Drum weights (mean per bird) are in Table 3. Again, the weights were heavier in males $(118 \mathrm{~g})$ than in females $(100 \mathrm{~g})$ at $35 \mathrm{~d}$. Neither dietary protein content $(b=0.0595 \pm 0.0717 \mathrm{~g} / \mathrm{g}$ protein) nor daylength $(-0.245 \pm 0.364 \mathrm{~g} / \mathrm{h})$ influenced drum weight, and there was also no interaction between the two factors. However, when the allometric relationships between $(I n)$ drum weight and (In) body protein weight on different daylengths were compared, the equation for the three longest daylengths $(0.087 \pm 0.834+0.805 \pm$ $0.145 \mathrm{~g} / \mathrm{g}$ ) differed from that for the $12 \mathrm{~h}$ treatment $(-2.303 \pm 1.18+1.224 \pm 0.207 \mathrm{~g} / \mathrm{g})$. Such differences did not occur when the relationships on the different feed protein levels were compared, nor was there an interaction between daylength and feed protein level.

Table 3 Mean breast, thigh, drum and wing weights $(\mathrm{g})$ of broilers at $35 \mathrm{~d}$ fed four levels of dietary protein and subjected to four lighting programmes

\begin{tabular}{|c|c|c|c|c|c|}
\hline \multirow[b]{2}{*}{ Light (h) } & \multicolumn{5}{|c|}{ Feed protein content $(\mathrm{g} / \mathrm{kg})$} \\
\hline & 143 & 164 & 184 & 204 & Mean \\
\hline & \multicolumn{5}{|c|}{ Breast } \\
\hline 12 & 412 & 362 & 385 & 383 & 385 \\
\hline 16 & 380 & 391 & 402 & 433 & 401 \\
\hline 20 & 364 & 444 & 455 & 532 & 449 \\
\hline 24 & 390 & 416 & 449 & 413 & 417 \\
\hline Mean & 386 & 403 & 423 & 440 & \\
\hline \multirow[t]{2}{*}{$\mathrm{RMS}^{1}$} & \multicolumn{5}{|c|}{3409} \\
\hline & \multicolumn{5}{|c|}{ Thigh } \\
\hline 12 & 132 & 122 & 118 & 126 & 123 \\
\hline 16 & 121 & 127 & 122 & 122 & 123 \\
\hline 20 & 112 & 132 & 133 & 147 & 131 \\
\hline 24 & 114 & 125 & 123 & 121 & 121 \\
\hline Mean & 119 & 126 & 124 & 129 & \\
\hline \multirow[t]{2}{*}{ RMS } & \multicolumn{5}{|c|}{359} \\
\hline & \multicolumn{5}{|c|}{ Drum } \\
\hline 12 & 109 & 107 & 98 & 120 & 108 \\
\hline 16 & 112 & 112 & 104 & 117 & 111 \\
\hline 20 & 104 & 116 & 108 & 111 & 110 \\
\hline 24 & 98.2 & 118 & 105 & 103 & 106 \\
\hline Mean & 105 & 113 & 104 & 113 & \\
\hline \multirow[t]{2}{*}{ RMS } & \multicolumn{5}{|c|}{251} \\
\hline & \multicolumn{5}{|c|}{ Wing } \\
\hline 12 & 87.0 & 86.7 & 80.8 & 94.9 & 86.3 \\
\hline 16 & 86.4 & 91.6 & 87.0 & 95.8 & 90.2 \\
\hline 20 & 85.5 & 87.4 & 90.8 & 94.6 & 89.6 \\
\hline 24 & 81.0 & 95.8 & 86.7 & 90.8 & 88.6 \\
\hline Mean & 83.9 & 90.4 & 86.3 & 94.0 & \\
\hline RMS & & & 139 & & \\
\hline
\end{tabular}


Mean wing weights of birds fed four levels of dietary protein content and reared under four lighting treatments to day 35 are given in Table 3 . The mean weight for females was $84 \mathrm{~g}$ and for males, $94 \mathrm{~g}(P$ $<0.001)$. Whereas there were differences in wing weights between feed protein treatments $(P<0.01)$, when these weights were regressed against feed protein content the regression coefficient was not different from zero $(0.116 \pm 0.052 \mathrm{~g} / \mathrm{g})$. There was also no trend when wing weight was regressed against daylength $(0.084 \pm 0.270 \mathrm{~g} / \mathrm{h})$. There was no interaction between treatments for wing weight. The allometric regression between $(I n)$ wing weight and $(I n)$ body protein weight of $0.467 \pm 0.372+0.6995 \pm 0.0649 \mathrm{~g} / \mathrm{g}$ remained the same over all dietary protein and daylength treatments, and the interaction between them.

Table 4 Mean breast weight $(\mathrm{g})$ as a proportion of body weight $(\mathrm{g})$ and body protein weight $(\mathrm{g})$ of broilers at $35 \mathrm{~d}$ fed one of four protein feeds and grown under different daylengths

\begin{tabular}{cccccc}
\hline & \multicolumn{5}{c}{ Dietary protein content (g/kg feed) } \\
Light (h) & $\mathbf{1 4 3}$ & $\mathbf{1 6 4}$ & $\mathbf{1 8 4}$ & $\mathbf{2 0 4}$ & Mean \\
\hline \multicolumn{5}{c}{ Breast weight/body weight } \\
12 & 0.186 & 0.174 & 0.196 & 0.175 & 0.183 \\
16 & 0.180 & 0.182 & 0.200 & 0.199 & 0.190 \\
20 & 0.182 & 0.196 & 0.208 & 0.222 & 0.202 \\
24 & 0.197 & 0.190 & 0.212 & 0.197 & 0.199 \\
\hline Mean & 0.186 & 0.185 & 0.204 & 0.198 & 0.193 \\
RMS & & & 0.031 & & \\
\hline
\end{tabular}

\section{Breast weight/body protein weight}

\begin{tabular}{cccccc}
12 & 1.35 & 1.25 & 1.33 & 1.19 & 1.28 \\
16 & 1.30 & 1.24 & 1.36 & 1.29 & 1.30 \\
20 & 1.27 & 1.36 & 1.45 & 1.50 & 1.40 \\
24 & 1.34 & 1.29 & 1.40 & 1.29 & 1.33 \\
\hline Mean & 1.32 & 1.28 & 1.38 & 1.32 & \\
RMS & & & 1.695 & & \\
\hline
\end{tabular}

RMS: Residual mean square, $\mathrm{n}=96$.

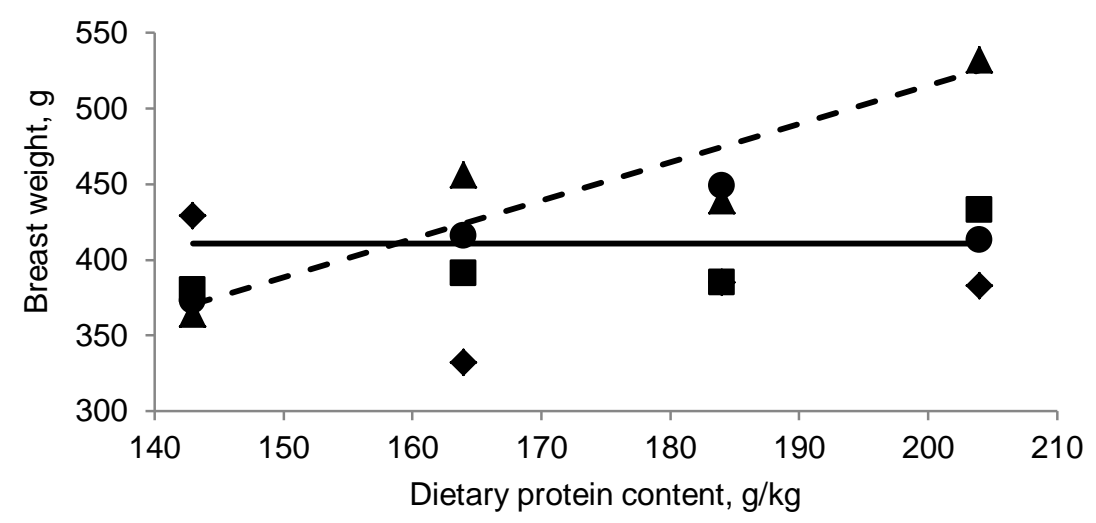

Figure 1 Response in breast weight (minus skin and bone) to increasing levels of dietary protein content for different daylengths. $12 \mathrm{~h} \bullet ; 16 \mathrm{~h}$-; $20 \mathrm{~h} \boldsymbol{\Delta} ; 24 \mathrm{~h} \bullet$. Broken line represents $20 \mathrm{~h}$ treatment; solid line represents the other three treatments. 


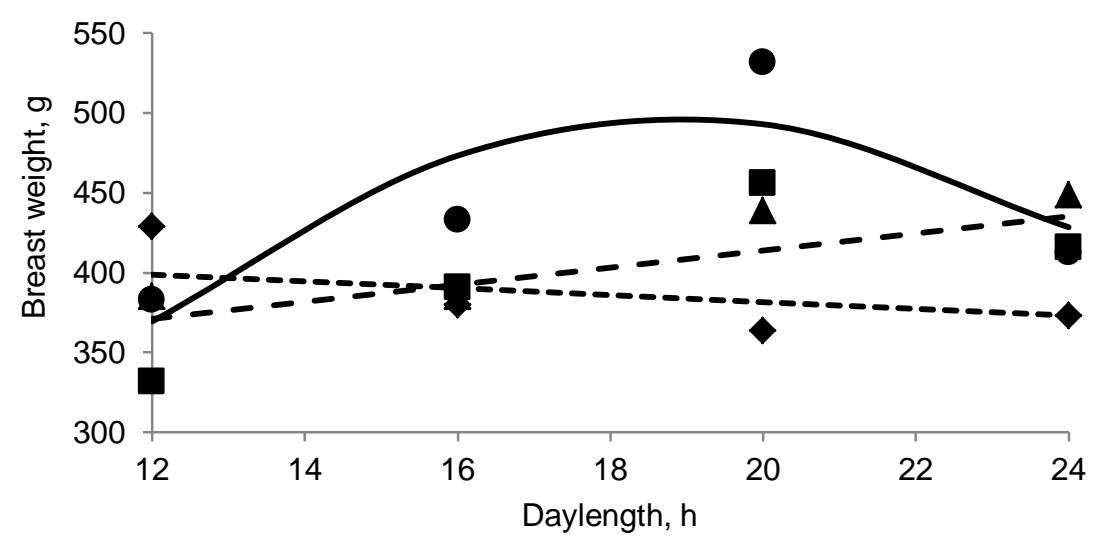

Figure 2 Response in breast weight (minus skin and bone) to increasing daylength on four dietary protein contents. Protein 143 ; 164

; 184

$\Delta-\cdots$ ; 204 $\bullet$

Mean body protein and lipid contents of broilers at $35 \mathrm{~d}$ are in Table 5 . There was no interaction $(P$ $>0.05$ ) between lighting programme and dietary protein content for either of these variables. Body protein content increased at the rate of $0.146 \pm 0.035 \mathrm{~g} / \mathrm{kg}$ as dietary protein content increased whereas body lipid content decreased $(-0.696 \pm 0.089 \mathrm{~g} / \mathrm{kg})$. Body protein also responded to daylength, increasing at the rate of $0.444 \pm 0.188 \mathrm{~g} / \mathrm{kg}$ per $\mathrm{h}$, but body lipid was unaffected $(P>0.05)$.

Table 5 Mean body protein and lipid contents $(\mathrm{g} / \mathrm{kg})$ at $35 \mathrm{~d}$ of broilers fed four levels of dietary protein and subjected to four lighting treatments

\begin{tabular}{cccccc}
\hline \multicolumn{5}{c}{ Feed protein content (g/kg feed) } \\
Light (h) & $\mathbf{1 4 3}$ & $\mathbf{1 6 4}$ & $\mathbf{1 8 4}$ & $\mathbf{2 0 4}$ & Mean \\
\hline \multicolumn{5}{c}{} & \multicolumn{5}{c}{ Body protein content (g/kg) } \\
12 & 138 & 140 & 148 & 146 & 143 \\
20 & 139 & 147 & 147 & 155 & 147 \\
24 & 143 & 145 & 144 & 148 & 145 \\
\hline Mean & 146 & 148 & 152 & 153 & 149 \\
RMS & 141 & 145 & 148 & 150 & \\
\hline & & & 58.7 & & 134 \\
12 & 165 & 133 & 115 & 121 & 142 \\
20 & 171 & 146 & 135 & 117 & 134 \\
24 & 153 & 145 & 132 & 120 & \\
\hline Mean & 153 & 143 & 123 & 116 & \\
RMS & 160 & 142 & 126 & 118 & \\
\hline
\end{tabular}

RMS: Residual mean square; $\mathrm{n}=96$.

\section{Discussion}

The objective of the trial reported here was to determine whether breast meat yield would improve in broilers reared on short daylengths if higher levels of dietary protein were fed. This was in response to reports in the literature indicating that breast meat yield is reduced when short daylengths are used in rearing (Renden et al., 1992; 1993; 1996; Downs et al., 2006; Schwean-Lardner et al., 2006; Brickett et al., 2007; Lien et al., 2007). Lewis et al. (2009) showed that feed intake was reduced on short days, suggesting that 
insufficient protein may be consumed under these conditions to enable broilers to express their potential breast meat yield.

Neither BWG to $35 \mathrm{~d}$ nor feed intake was affected by the amount of light given to the birds. It has been demonstrated (Lewis et al., 2009) that broilers learn to eat in the dark when subjected to daylengths shorter than $16 \mathrm{~h}$, and this enables them to compensate for the reduced daylength. These results confirm those of Lewis et al. (2009; 2010) that broilers grow as well on short as on long days, and that their welfare, as judged in this case by mortality to $35 \mathrm{~d}$, is jeopardised when long daylengths are used in the rearing period. FCE to $21 \mathrm{~d}$ was improved with the use of short daylengths although this advantage disappeared by $35 \mathrm{~d}$, the lack of a significant trend possibly being the result of too few replications of the main treatments. Whereas the number of replications may have been insufficient for measuring differences in growth rate and FCE, significant differences between treatments were observed in the physical and chemical composition of broilers on the different treatments, this being the objective of the exercise.

The effects of the dietary and environmental treatments on breast meat yield were complex, and largely dependent on the method used to describe these effects. When viewed over all lighting treatments dietary protein content had no effect on breast meat yield except in those broilers receiving $20 \mathrm{~h}$ light/d. However, breast meat yield on the lighting treatments differed considerably depending on the dietary protein content given; decreasing on the lowest protein, increasing linearly on the next two protein levels (164 and $184 \mathrm{~g} / \mathrm{kg}$ ), and showing a curvilinear trend on the highest protein feed. Birds on $20 \mathrm{~h}$ of light and fed the highest protein content had considerably heavier breast weights than on any other treatment and could therefore have been regarded as being outliers, these results having a significant effect on the response to $20 \mathrm{~h}$ and $204 \mathrm{~g}$ protein/kg. However, these birds were also the heaviest birds sampled, thus, when breast weights were expressed as a proportion of body weight, or of body protein weight, differences between treatments were not as apparent. These differences all-but disappeared when the allometric relationship between breast weight and body protein weight were compared between treatments: the slope of this regression was the same in all treatments, but was adjusted upwards (higher constant term) in the case of broilers given $20 \mathrm{~h}$ light/d.

Emmans \& Fisher (1986) and Danisman \& Gous (2011) have argued that the logical way to predict the effects of genotype, feed and environment on the growth of breast meat and other body components is to express the component as a proportion of body protein growth. Potential protein growth rates have been described for various genotypes (Hancock et al., 1995; Gous et al., 1996) using a Gompertz growth function (Gous et al., 1999) and simulation models already exist for predicting the actual growth of body protein as influenced by genotype, feed and environment (Emmans, 1981; EFG Software, 2007). Such models may therefore be used to predict the growth of any scaled component of the body, as any components that share the same rate of maturing can be scaled allometrically (Emmans, 1987; 1988). What is needed for each genotype is a description of the potential rates of growth of body protein and of the different components of the body so that the allometric relationships between the important components of the body and body protein can be determined. Differences in the allometric relationships between genotypes, or those brought about through nutritional or environmental manipulation would enable these effects to be modelled. The results reported here do not disprove the hypothesis that the allometric regression coefficient between breast weight and body protein weight is the same under all circumstances, and that differences in the constant term may be brought about by different nutritional or environmental conditions.

Danisman \& Gous $(2011 ; 2013)$ suggested that the shift in constant term was due to an increased amount of body lipid being deposited in the different components of the body when birds are placed on low protein feeds. In this trial, body lipid content decreased, as predicted, but in addition, body protein content increased with dietary protein content. Body protein also increased with daylength whereas body lipid was unaffected. Increases in body protein would result in increased breast weights, as described by the allometric coefficient given above, whereas increased body lipid growth would change the constant term in the allometric equation. Because body lipid was unaffected by daylength, these results do not provide substantial underlying evidence that the constant term in the allometric equation may be altered by different daylengths. Some other explanation is needed to model the reduction in breast meat yield in broilers reared on daylengths shorter than $20 \mathrm{~h}$.

The response in thigh weight to dietary protein and to daylength was interesting, and similar to that in breast weight, with the weights increasing with daylength in birds fed the three highest dietary protein levels, but with birds on the lowest protein exhibiting reduced thigh weights as daylength was increased. Unlike the case with breast meat, the allometric relationship between thigh weight and body protein weight was the same over all dietary protein and lighting treatments, differences in lipid content between treatments presumably being less than in the trials by Danisman \& Gous $(2011 ; 2013)$ where the constant term in this relationship was shifted upwards when broilers were fed the lowest protein feeds. 
Drum weights were unaffected by dietary protein content and daylength, and there was also no interaction between the two factors. However, the allometric equation describing drum weight in terms of body protein weight for the three longest daylengths differed from that for the $12 \mathrm{~h}$ treatment, the latter starting at a lower constant term but with a steeper slope than the equation for the other treatments. It is unusual for the slope of the allometric regression for drum weight to differ between treatments: when comparing different genotypes, sexes and feed protein levels in two extensive trials, Danisman \& Gous $(2011 ; 2013)$ showed only one instance where the allometric regression coefficients differed, and this was between four genotypes and not between sexes or dietary protein levels. In this trial also, no differences in the allometric relationship between drum and body protein were evident between different feed protein levels, nor was there an interaction between daylength and feed protein level. The difference observed here may have been an anomaly of the data collected rather than a true effect of different daylengths, given both the prior evidence with drum weight and the lack of such differences with the other component weights in this trial.

Whereas there were differences in wing weights between feed protein treatments as revealed using ANOVA, when these weights were regressed against feed protein content the regression coefficient was not different from zero. There was also no trend when wing weight was regressed against daylength. It is important to bear in mind that the trial conducted here was a response trial where the levels of the treatments are not independent, and hence the trends resulting from the imposition of dietary protein levels and daylengths are of importance, and not whether there are differences between treatment means (see Morris, 1983; 1999). As with thigh weight, the allometric regression between wing weight and body protein weight remained the same over all dietary protein and daylength treatments. This confirms the results of the trials reported by Danisman \& Gous $(2011 ; 2013)$ although Brickett et al. (2007) reported that drum and wing weights at $35 \mathrm{~d}$ were heavier on their low protein diet.

\section{Conclusion}

Breast meat yield from birds reared on $12 \mathrm{~h}$ was not improved when these birds were fed high protein feeds whereas yields were increased in birds on the three longer daylengths used when feed protein was increased. The decreased breast meat yield in broilers given short daylengths is therefore not the consequence of a shortage of dietary protein. Nevertheless, the allometric regression between breast meat and body protein content remained the same for all daylengths used thus confirming that breast meat yield may be accurately predicted from body protein weight.

\section{References}

AOAC, 2003. Official methods of analysis. $17^{\text {th }}$ Edition. Association of official analytical chemist, Inc., Arlington, Washington, USA.

Aviagen, 2009. Broiler nutrition specifications. http://en.aviagen.com/assets/Tech_Center/AA_ Broiler_Nutrition_Specs. (Accessed, August 2009).

Brickett, K.E., Dahiya, J.P., Classen, H.L. \& Gomis, S., 2007. Influence of dietary nutrient density, feed form, and lighting on growth and meat yield of broiler chickens. Poult. Sci. 86, 2172-2181.

Danisman, R. \& Gous, R.M., 2011. Effect of dietary protein on the allometric relationships between some carcass portions and body protein in three broiler strains. S. Afr. J. Anim. Sci. 41, 194-208.

Danisman, R. \& Gous, R.M., 2013. Effect of dietary protein on performance of four broiler strains and on the allometric relationships between carcass portions and body protein. S. Afr. J. Anim. Sci. 43, 25-37.

Downs, K.M., Lien, R.J., Hess, J.B., Bilgili, S.F. \& Dozier III, W.A., 2006. The effects of photoperiod length, light intensity, and feed energy on growth responses and meat yield of broilers. J. Appl. Poult. Res. 15, 406-416.

EFG Software 2007. http://www.efgsoftware.net/ (accessed July 2013).

Emmans, G.C., 1981. A model of the growth and feed intake of ad libitum fed animals, particularly poultry. In: Computers in Animal Production. Br. Soc. Anim. Prod. 5, 103-110.

Emmans, G.C., 1987. Growth, body composition and feed intake. Wrld Poult. Sci. J. 43, 208-227.

Emmans, G.C., 1988. Genetic components of potential and actual growth. In: Animal Breeding Opportunities. Occ. Pub. No 12. Br. Soc. Anim. Prod., Penicuik, Midlothian, U.K. pp. 153-181.

Emmans, G.C. \& Fisher, C. 1986. Problems in nutritional theory. In: Nutrient Requirements of Poultry and Nutritional Research. Eds: Fisher, C. \& Boorman, K.N., Butterworths, London. pp 9-40.

European Union, 2007: Council Directive 2007/43/EC. Pages 19-28 in Official J. Eur. Union, L182, Vol. 50.

Fisher, C. \& McNab, J.M., 1987. Techniques for determining the ME content of poultry feeds. In: Recent Advances in Animal Nutrition. Eds: Haresign, W. \& Cole, D.J.A., Butterworths, London. pp. 3-17.

GenStat 2011. GenStat statistical software, $14^{\text {th }}$ Edition. Lawes Agricultural Trust. Hemel Hempstead, U.K. 
Gous, R.M., Emmans, G.C., Broadbent, L.A. \& Fisher, C., 1990. Nutritional effects on the growth and fatness of broilers. Br. Poult. Sci. 31, 495-505.

Gous, R.M., Pym, R.A.E., Mannion, P. \& Wu, J.X., 1996. An evaluation of the parameters of the Gompertz growth equation that describe the growth of eight strains of broiler. Aust. Poult. Sci. Symp. 8, 174-177, University of Sydney, Sydney, NSW, Australia.

Gous, R.M., Moran Jr., E.T., Stilborn, H.R., Bradford, G.D. \& Emmans, G.C., 1999. Evaluation of the parameters needed to describe the overall growth, the chemical growth and the growth of feathers and breast muscles of broilers. Poult. Sci. 78, 812-821.

Hancock, C.E., Bradford, G.D., Emmans, G.C. \& Gous, R.M., 1995. The evaluation of the growth parameters of six strains of commercial broiler chickens. Br. Poult. Sci. 36, 247-264.

Ingram, D.R., Hatten III, L.F. \& McPherson, B.N., 2000. Effects of light restriction on broiler performance and specific body structure measurements. J. App. Poult. Res. 9, 501-504.

Lewis, P.D. \& Gous, R.M., 2007. Broilers perform better on short or step-up photoperiods. S. Afr. J. Anim. Sci. 37, 90-96.

Lewis, P.D., Danisman, R. \& Gous, R.M., 2008. Male broiler performance and nocturnal feeding under constant 8-h or 16-h photoperiods, and various step-up lighting regimens. S. Afr. J. Anim. Sci. 38, 159-165.

Lewis, P.D., Danisman, R. \& Gous, R.M., 2009. Photoperiodic responses of broilers. I. Growth, feeding behaviour, breast meat yield, and testicular growth. Br. Poult. Sci. 50, 657-666.

Lewis, P.D., Danisman, R. \& Gous, R.M., 2010. Welfare-compliant lighting regimens for broilers. Arch. Geflugelkd.74, 265-268.

Lien, R.J., Hess, J.B., McKee, S.R., Bilgili, S.F. \& Townsend, J.C., 2007. Effect of light intensity and photoperiod on live performance, heterophil-to-lymphocyte ration, and processing yields of broilers. Poult. Sci. 86, 1287-1293.

Morris, T.R., 1983. The interpretation of response data from animal feeding trials. In: Recent Advances in Animal Nutrition. Ed: Haresign, W., Butterworths, London. pp. 12 - 23.

Morris, T.R., 1999. Experimental Design and Analysis in Animal Sciences. CABI Publishing, Wallingford, U.K.

Renden, J.A., Bilgili, S.F. \& Kincaid, S.A., 1992. Live performance and carcass yield of broiler strain crosses provided either sixteen or twenty-three hours of light per day. Poult. Sci. 71, 1427-1435.

Renden, J.A., Bilgili, S.F. \& Kincaid, S.A. 1993. Research note: Comparison of restricted and increasing light programs for male broiler performance and carcass yield. Poult. Sci. 72, 378-382.

Renden, J.A., Bilgili, S.F. \& Kincaid, S.A. 1996. Lighting programs for broilers that reduce leg problems without loss of performance or yield. Poult. Sci. 75, 1345-1350.

Schwean-Lardner, K., Classen, H.L. \& Fancher, B.I., 2006. Increasing lighting program effects on production characteristics of modern broilers. Poult. Sci. 86, (Abs. 137) 165.

Smith, E.R. \& Pesti, G.M., 1998. Influence of broiler strain cross and dietary protein on the performance of broilers. Poult. Sci. 77, 276-281. 